\title{
RISK PERCEPTION AND THE \\ PRACTICES TOWARDS COVID-19 \\ AMONG THE GARMENT WORKERS IN BANGLADESH
}

\author{
Shamima AKTER ${ }^{1}$ \\ Shafia SHAHEEN2 \\ DOI: https://doi.org/10.35782/JCPP.2021.4.0토
}

\begin{abstract}
Coronavirus disease 2019 is caused by Novel corona virus (SARS-CoV-2). The World Health Organization declared it as Public Health Emergency of International Concern (PHEIC) on 30 January 2020 and as a global pandemic on 11th March 2020 (WHO). The first cases were detected in Bangladesh on 08th March 2020. The aim of the study was to assess the level of risk perception towards COVID-19 and the practices of preventive measures to fight against COVID-19 among the garment workers. A cross-sectional study was conducted from 20th December 2020 to 7th January 2021 among the garment workers of selected garment industries at Savar, Dhaka. The results show that the respondents well knew about COVID-19 as a viral, contagious disease and more than $94 \%$ knew that coronavirus infected patient needed isolation. The majority of the respondents (86.2\%) got information about COVID-19 from television. Eighty percent of the respondents had a bigh-risk perception of being infected, the severity of the disease, and the possibility of death. Among the respondents, $76 \%$ had good practices of preventive measures of COVID-19. The study result showed that the level of risk perception had a significant positive relationship with the level of practices towards COVID-19 among the garment workers. It was recommended that emphasis should be given on awareness about COVID-19 which would enhance perceived risk and practices of precautionary measures towards COVID-19.
\end{abstract}

Keywords: risk perception, knowledge, practices, garment workers in Bangladesh, COVID-19

1 Medical Officer, Bangladesh Public Administration Training Centre, Dhaka, email: shamimaakterdr@gmail.com

2 Assistant Professor, Department of Epidemiology, National Institute of Preventive and Social Medicine, Dhaka, email: sshaheen69@yahoo.com 


\section{Introduction}

Corona virus disease 2019 (COVID -19) is caused by Severe Acute Respiratory Syndrome Corona Virus-2 (SARS-CoV-2). It is an enveloped positive RNA viruses, family Coronaviridae and the order Nidovirales (Taghrir, Borazjani and Shiraly, 2020). SARS-COV, MERS-COV and the currently appeared SARS CoV-2 are corona viruses. SARS-COV-2 is included in Beta genus. The virus mainly causes respiratory illness (Hossain, 2020). SARS-COV-2 was first detected in Wuhan, Hubei province, China, in December 2019. This virus is alike with bats corona virus (more than 95\%) and SARSCoV-2 (more than 70\%). It encompasses higher morbidity and mortality than other human corona viruses such as severe acute respiratory syndrome (SARS) and Middle East Respiratory Syndrome (MERS) (Bruine de Bruin and Bennett, 2020).The basic reproductive number (R0) of SARS-CoV-2 is 3.28 which is greater than SARS (2.7) and 2009 pandemic H1N1influenza (2.4) (Harapan et al., 2020). According to Li Q, et.al., Severe Acute Respiratory Syndrome Coronavirus-2 (SARS-Cov-2) spreads from person to person through sneezing, coughing, touching contaminated objects referred in (Olum and Bongomin, 2020). This virus utilizes host receptor angiotensin-converting enzyme 2 (ACE2) to penetrate the cells that enhances the capacity of transmission from person to person. Its incubation period is 4 to 14 days and clinical symptoms of COVID-19 vary from mild to moderate respiratory symptoms. According to WHO report, more than $80 \%$ of cases had mild symptoms who recovered without medical intervention, 20\% became critically ill cases (World Health Organization, 2020). Case fatality is depended upon the age of the individual, interconnected to comorbidities, isolation facilities accessibility and competency of health care systems. Mortality rate is more among the persons who are above 80 years (Bedford et al., 2020). The main clinical symptoms of COVID-19 are fever, dry cough, sore throat, loss of taste or smell, fatigue, headache myalgia, dyspnea (Zhong et al., 2020). Several severe complications are developed in COVID-19 patients such as acute distress respiratory syndrome (ARDS), hypoxemia, acute cardiac injury, acute lung injury, shock and arrhythmia. The worldwide case fatality of COVID-19 is 2.17. The first three cases were reported in Bangladesh on $8^{\text {th }}$ March 2020 (IEDCR, 2020). Case fatality rate was $1.5 \%$ (DGHS, 2021). The extent and speedy proliferation of COVID-19 from symptomatic and asymptomatic patients made anxious to recognize the behavioral action of people (Ferdous et al., 2020).

The declaration of complete lock down came from Bangladesh government on 24 March to 4 April, which was extended till 25 April 2020. Recently some vaccines against Covid-19 have been available such as Pfizer- BioNTech Covid-19 vaccine, Moderna Covid-19 vaccine, and Oxford-AstraZeneca COVID-19 vaccine. It is hard to make available COVID-19 vaccine for all within short time. Hence, prevention is the main way to get rid from it. To attain success against COVID -19, effective control measures are necessary.

Risk perception is a part of individual's decision making process which affects compliance with public health messages for optimistic behaviors (Mainous, 2020). Bangladesh is one of the most vulnerable countries in South Asia, regarding spread of COVID-19 among different segments of working people like health care providers, 
bankers, law enforcing personnel, media people, readymade garment (RMG) workers and other industrial labor. Closing almost all sectors, the government within few days allowed by the demand of the export oriented RMG industries to open proper instructions regarding COVID-19 and declared incentive packages. In worse circumstances, the garment workers protested on the street for their payment, violating the lockdown. Hence, the RMG workers became more exposed to be affected by the COVID-19. However, this study entailed the knowledge, risk perception and practices of COVID-19 among the garment workers in Bangladesh.

Bangladesh is one of the leading clothing exporters, second position in the world. There are 4621 garment factories in Bangladesh, where 4.2 million of people are working. In pandemic situation the low socio-economic vulnerable population of garment workers (Chowdhury, N. J \&Ullah, 2010) should be aware about this infectious disease which help them to prevent the infection. The aim of this study was to assess risk perception and practice towards COVID -19 among garment workers in Bangladesh.

COVID-19 as a new disease so there is no specific treatment available. The best way is prevention of the disease. The prevention of an infectious disease mainly depends upon knowledge, risk perception, attitude, and practices of people regarding the disease. The Health Belief Model developed by Janz and Becker in 1984, explains the necessity of risk perception and practices (van der Pligt, 1996). The aim of the study was to assess risk perception and practices on COVID-19 among garment workers in Bangladesh in respect of socio-demographic and working environment factors. Hence this study was confined to see the level of knowledge, risk perception and practices and sociodemographic and working environment factors among the garment workers in Bangladesh. Though there are many studies on knowledge, attitude, and risk perception and health behavioral practices regarding COVID-19 worldwide on different content and context especially on health care providers. However, the present study was totally different in content and context of garment workers in Bangladesh. It was expected that the findings of the study will benefit the future epidemiological research work, contribute to the existing literature of health behavioral science as well as at the policy level to take necessary steps for prevention and control of COVID-19. This study also tried to facilitate the future researchers to find out and compare the condition of Bangladesh and other countries.

This study attempted to reveal the answer of the question of what is the level of risk perception and the practices towards COVID-19 among the garment workers with specific objectives are i) to assess the level of knowledge among the garment workers about COVID-19; ii) to assess the perceived risk to be infected by COVID-19 among the garment workers; iii) to identify the practices of preventive measures regarding COVID-19 among the garment workers and to explore the relationship between risk perception and practice regarding COVID-19 of garments workers. This study is not beyond some limitations as I was employed convenience non-probability sampling technique. The garment factories were selected conveniently so it is difficult to generalize the findings. A cross-sectional study design was used so causal inferences may not be established. 


\section{Literature Review}

COVID-19 influenced the global economic condition such as shipping, leisure, tourism, luxury commodities. Garment industry is one of the most vulnerable sectors as China is the core country for raw materials of garment industry where COVID-19 began (Sen, Ahmed, et al., 2020). In Bangladesh garment industries drive the country's economic growth, contributing to economic growth rate. Large percent of population are working in this sector (Chowdhury, N. J \& Ullah, 2010). Garment workers are more vulnerable for various diseases especially infectious disease like COVID-19 (Sen, Antara, et al., 2020). They also (Sen, Antara, et al., 2020) stated that in pandemic situation garments workers have to work with minimal safety measures and social distancing is not maintained properly in most of the garment factories.

\subsection{Knowledge}

Knowledge regarding COVID-19 includes learned about cause, transmission of the disease, symptoms, prevention and control of the disease. Zhong et al., 2020 in their first study on knowledge, attitude and practices regarding COVID-19 found that $90 \%$ of respondents had high knowledge about COVID-19 and high knowledge had an important association with improvement of practices and optimistic attitude. Azlan, 2020, in a study found that respondents had moderate knowledge scores, answered 80.5\% correctly of knowledge related questions regarding COVID-19. A study on general people of Iran showed that $60.8 \%$ respondents had moderate knowledge about COVID-19 and also established that male gender, non-health care occupations, single and lower education level were significantly linked with lower knowledge scores (Erfani et al., 2020). A study by Al-Hazmiet al. (2018) demonstrated that most of the respondents mentioned that hand washing was the method of prevention of spreading the disease.

\subsection{Importance of sources of information}

Polling by Reuters in United State found that Internet is the best source of information; other important sources are Face book, Twitter, television, radio, and newspaper. Sources of information have important role on risk perception and health behavior. In pandemic situation all the countries in the world campaign on preventive measures and raise awareness about COVID-19. Ronald (2020), in their study revealed that $78 \%$ used mass media and $76 \%$ used social media as source of information. Luu and Huynh (2020), in their survey evaluated that geography and social media were two significant determinants of perception and social media had optimistic effect on risk perception and practices of preventive measures

\subsection{Risk Perception}

Risk refers to the likelihood of loss which consist of chance and severity of harmful effect (van der Pligt, 1996). Risk perceptions are beliefs about potential harm or the possibility of a loss. Risk perception has three dimensions 1) perceived likelihood 
2) perceived susceptibility 3) perceived severity (Darker C. 2013). On the other hand, (Cori et al., 2020) stated that elements which enhance or diminish risk perceptions are voluntariness, knowledge, visibility and trust Dryhurst et al., 2020, found in their study that trusts on government negatively associated with risk perception and personal knowledge had positive relationship with risk perception. More precisely, Bruine de Bruin and Bennett (2020), in their investigation evaluated a strong positive relationship that participants who perceived higher risk executed more protective health behaviors.

\subsection{Practices on Covid-19}

Xiao and Torok (2020) stated that main important have to be given on epidemiology of the infection, clear idea about risk of it. The education must be scientific. Prevention and control of the infection is the greatest approach to get free from it. Using face mask is the key method suggested by The World Health Organization (WHO) and the United States Centers for Disease Control (CDC). Aruhomukama et al. (2020) in their study estimated that $77.0 \%$ participants had knowledge of right procedure of face masking and older people and male participants had less trust that face masking is a good preventive measure against COVID-19. Similarly, a study by Abdulah et al. (2020) explored that $69.2 \%$ of respondents utilized face masks or tissue papers during coughing or sneezing in public places, $94.6 \%$ practiced hand hygiene and $84.6 \%$ cleaned suspected contaminated areas by disinfectants.

\subsection{Working environment}

The health and security of industrial employees in Bangladesh are provided by the Bangladesh Labor Act 2006. Section 51 to 60 on Health and Hygiene related provisions. Section 61 to 78 are safeguard in case of fire, frame of apparatus work on or near machines in motion hoist and extreme weights carrying (Rashid, Rashid, 2015). On the other theme, Md. Lokman Ali (2017) refers that environmental factors may be direct factors and indirect factors. Direct factors are interconnected to workplace like physical atmosphere of the garments, salary, and work hours, behaviors of supervisors, healthcare services, and sexual annoyance. Indirect factors are related to living place and during traveling to workplace and workplace to home

\subsection{Theoretical models of health behavior}

Protection motivation theory was developed in 1975, by Dr. R.W Rogers which stated two parts one is threat assessment process that depends upon the severity and the vulnerability of the event and the rewards. Another one is the coping appraisal procedure which refers to how an individual reacts to the event and comprises of efficacy and self-efficacy and reaction expenses. In 1983 Dr. R.W Roger recognized five possible copping modes- i) inhibition of a action ii) single act iii) repeated act iv) multiple act v) repeated multiple acts (Clubb and Hinkle, 2015). Meta-analysis conducted by Floyd, Prentice-Dunn and Rogers in 2000 identified that severity, response efficacy and self-efficacy had positive relationship with preventive behaviors while rewards and response expenses had negative correlation (Prentice-Dunn, McMath 
and Cramer, 2009).A study by Rad, 2020based on the Protection Motivation Theory (PMT) identified that motivation protection was significantly associated with protective behavior regarding COVID-19.

Additionally, there are several models those are developed to clarify why individual follow protective actions or why not. The major models are i) Cost-benefit model which derived from value expectancy theory, ii) environmental or contextual model and iii) behavior change process itself (DeJoy, 1996). Value expectancy theory explains that individual evaluate the severity of risk, cost, and benefit of measures. Weinstein, (1993) described that this theory has four common features a)inspiration for selfdefending behavior $b$ ) perception about the possibility of negative consequence of the event c)stimulus that the action will decrease the likelihood of the damage d)impulse that the projected benefits of a meticulous deed must be reflected on the anticipated expenditure of taking action (DeJoy, 1996). Correspondingly, health belief model refers five elements, as such a) perception of vulnerability to health outcome b) perceived severity of the event c) the perceived profit interrelated to explicit action d) the perceived difficulty allied with the particular action e) specific cues to action (DeJoy, 1996). Furthermore, transtheoretical model came out from a comparative analysis of important theories of psychotherapy and behavior change. Prochaska and colleagues stated the process of behavior change that has 5 principle steps a) precontemplation $\mathrm{b}$ ) contemplation c) preparation d) action e) maintenance referred by (DeJoy, 1996).

\subsection{Risk perception and practices towards COVID-19}

Kwok et al. (2020), in their study in Hong Kong, revealed that $89 \%$ respondents had high perception of susceptibility to be infected with COVID-19 and 97\% were highly perceived of severity of the disease Serwaa et al., 2020, in their study showed that $61.7 \%$ respondents had excellent knowledge regarding COVID-19, 68.3\% covered high risk perception and $81.4 \%$ had moderate preparedness ability to take action against COVID-19.A study by Kebede et al. (2020) demonstrated $41.3 \%$ respondent had high knowledge regarding COVID-19, 77.3\% frequently wash their hands and 53.8\% kept away themselves from hand shaking(Kebede et al., 2020). Alsoghair et al. (2021) in their study demonstrated that $94.1 \%$ of respondents had high level of protective behaviors against COVID-19; also found that risk perception and preventive behaviors was positively correlated. A study made a comparison between uses of face mask before and after epidemic and showed the wearing of face mask was highly increased during pandemic (97.4\%) than before outbreak (11.3\%) of COVID-19 (Chan et al., 2020). Abdelrahman (2020), in their study, found that more than $95 \%$ respondents stated that they applied cleanliness and hand hygiene; also showed that carefulness, neuroticism, threat perception influenced the practice of social distancing.

\section{Methods and Resources}

A cross sectional study was done for measuring the level of knowledge, risk perception and practices towards COVID-19 among the garment workers. The study population of this research was both male and female garment workers who had been working in the selected garment industries for the last six months of data collection at the age of 18 
years and above and management personnel. Previous studies were considered. In their study, Kyaw S. Mya and others carried out about perceived risk among adults at Yangon and Bago regions in Myanmar and found that 22.8\% in high risk perception category (Mya et al., 2020). It was considered $22.8 \%$ proportion of high-risk perception for getting the sample size of 299 but the actual number of respondents was 305 . Convenience, non-probability sampling technique was applied, and samples were selected from the garment factories located at Savar, Dhaka. Observation and face to face interview methods were performed and a semi-structured questionnaire and checklist were developed, and SPSS and Excel were used for data analysis. Both descriptive and inferential analysis were performed.

\section{Ethical consideration}

The Institutional Review Board (IRB) of The National Institute of Preventive and Social Medicine (NIPSOM) provided an ethical clearance of the study. An informed consent was obtained from each respondent explaining the objectives, purposes, procedures, probable risks, and benefits. The respondents were reassured that strict confidentiality will be maintained in data handling, processing, and analyzing and the data would be used only for academic purposes with anonymity.

\section{Results of the Study}

The data analysis was done using descriptive statistics for getting mean, median, standard deviation, frequencies, and percentages. Bivariate correlation was used to find relationship between two continuous variables. In addition, chi squared test was used to compare categorical variables. The results are illustrated in this section with tables and diagrams.

\subsection{Socio-demographic characteristics of the respondents}

The total number of respondents was 305 for this study. The results showed that most of the $(38.0 \%)$ respondents age $18-25$ years, the mean age of the participants 28.40 years with $\mathrm{SD} \pm 5.70$, the maximum age was 47 years and minimum age was 18 years. Among 305 participants $40 \%$ were male, and $60 \%$ were female. The most of the participant's religion in this study was Islam (84.3\%),79\% were married. This study illustrated that about half of the spouse's occupation was garment worker $(45.6 \%)$, $19 \%$ service, $11.1 \%$ business, $6.6 \%$ others such as farmer, housewife, $1.6 \%$ are unemployed. About half of the participant's educational status was secondary $(47.87 \%)$, $26.89 \%$ was primary, $20.66 \%$ was higher secondary, $3.61 \%$ was undergraduate and $0.98 \%$ was Master's level. The majority of the spouses had completed secondary level education (49.2\%), 25\% primary, $22.7 \%$ higher secondary, $2.7 \%$ undergraduate and only $0.4 \%$ Master's level of education. The minimum and the maximum number of residents in a room was 1 and 8 respectively. Majority of the respondents $178(58.4 \%)$ answered the number of residents was 1-3. The table below demonstrated that 
68 Risk perception and the practices towards Covid-19

participants mainly living with nuclear family about $41 \%, 39.7 \%$ live in sublet, $19.3 \%$ living with joint family.

\subsection{Knowledge on COVID-19}

COVID-19 is a viral disease. Table 1. provided the information about the knowledge of the participants about the type of COVID-19 disease. $94.4 \%$ participants answered that COVID-19 was a viral disease, $2 \%$ answered that it was not a viral disease and $3.6 \%$ answered that they did not know the type of the disease (See Table1).

Table 1. Distribution of knowledge

about COVID-19 as a virus

\begin{tabular}{|l|c|c|}
\hline \multicolumn{3}{|c|}{$\mathrm{n}=305$} \\
\hline COVID-19 a viral disease & Frequency & Percentage (\%) \\
\hline Yes & 288 & 94.4 \\
\hline No & 6 & 2.0 \\
\hline Don't know & 11 & 3.6 \\
\hline Total & 305 & 100.0 \\
\hline
\end{tabular}

Corona virus is contagious. All the participants responded the question about contagiousness of the virus. The table below demonstrated that most of the participants answered that corona virus was contagious and $4.6 \%$ answered that it was not contagious and $8.5 \%$ answered that they didn't know (See Table 2).

Table 2. Distribution of knowledge

as corona virus is contagious

$\mathrm{n}=305$

\begin{tabular}{|l|l|l|}
\hline \multicolumn{1}{|c|}{ Corona virus is contagious } & \multicolumn{1}{|c|}{ Frequency } & \multicolumn{1}{c|}{ Percent } \\
\hline Yes & 265 & 86.9 \\
\hline No & 14 & 4.6 \\
\hline Don't know & 26 & 8.5 \\
\hline Total & 305 & 100.0 \\
\hline
\end{tabular}

Knowledge regarding symptoms of COVID-19. All the participants responded the multiple questions and individual responded differ from each other.97.7\%answered fever as a symptom of COVID-19, 59.3\% responded headache, 77\% reported dry cough, $72.8 \%$ answered sore throat, $34.4 \%$ answered weakness, $63 \%$ answered breath difficulties, $26.2 \%$ responded tiredness, $27.2 \%$ answered nasal congestion, $24.6 \%$ answered diarrhea, loss of taste or smell answered $12.5 \%$ and $0.7 \%$ said that they didn't know (See Table 3). 
Table 3. Distribution of knowledge on symptoms of COVID-19 frequencies

$\mathrm{n}=305$

\begin{tabular}{|l|c|c|}
\hline \multicolumn{1}{|c|}{ Symptoms of COVID-19 } & Frequency & Percentage \\
\hline Fever & 298 & $97.7 \%$ \\
\hline Headache & 181 & $59.3 \%$ \\
\hline Dry Cough & 235 & $77.0 \%$ \\
\hline Sore Throat & 222 & $72.8 \%$ \\
\hline Weakness & 105 & $34.4 \%$ \\
\hline Breath Difficulties & 192 & $63.0 \%$ \\
\hline Tiredness & 80 & $26.2 \%$ \\
\hline Nasal congestion & 83 & $27.2 \%$ \\
\hline Diarrhea & 75 & $24.6 \%$ \\
\hline Loss of Taste or smell & 38 & $12.5 \%$ \\
\hline Don't know & 2 & $0.7 \%$ \\
\hline \multicolumn{2}{|c|}{$*$ (Participants selected multiple answers) }
\end{tabular}

Knowledge about preventive measures of COVID-19. The respondents were asked about the preventive measures of COVID-19. The respondents opined hand washing with soap $(99.3 \%)$, wearing face mask $(79 \%)$, using hand sanitizer $(66.6 \%)$, maintain social distancing $(56.7 \%)$, avoid public gathering $(49.2 \%)$, maintain cough etiquette $(39.7 \%)$ and vaccine $16.1 \%$ (See Table 4$)$.

Table 4. Knowledge about preventive measures of COVID-19

$\mathrm{n}=305$

\begin{tabular}{|l|c|c|}
\hline \multicolumn{1}{|c|}{ Preventive measures of COVID-19 } & Frequency (Yes) & Percentage (\%) \\
\hline Hand washing with soap & 303 & 99.3 \\
\hline Using hand sanitizer & 203 & 66.6 \\
\hline Wearing face mask & 241 & 79 \\
\hline Maintain cough etiquette & 121 & 39.7 \\
\hline Avoid public gathering & 150 & 49.2 \\
\hline Maintain social distancing & 173 & 56.7 \\
\hline vaccine & 49 & 16.1 \\
\hline Don't know & 0 & 0 \\
\hline others & 2 & 0.7 \\
\hline \multicolumn{2}{|r|}{$*$ (Participants selected multiple answers) } \\
\hline
\end{tabular}

Knowledge regarding spread of COVID-19. The participants were asked about the way of spreading COVID-19. All the participants (100\%) said that COVID-19 spread through sneezing, 72.1\% answered through coughing, 61.6\% responded touching contaminated objects and only $0.3 \%$ said that they didn't know. (See Table 5) 
70 | Risk perception and the practices towards Covid-19

Table 5. Distribution of knowledge about spreading COVID-19

$\mathrm{n}=305$

\begin{tabular}{|l|c|c|}
\hline \multicolumn{1}{|c|}{ Spread of COVID-19 } & Frequency & Percentage \\
\hline Sneezing & 305 & $100.0 \%$ \\
\hline Coughing & 220 & $72.1 \%$ \\
\hline Touching object & 188 & $61.6 \%$ \\
\hline Don't know & 1 & $0.3 \%$ \\
\hline others & 12 & $3.9 \%$ \\
\hline
\end{tabular}

Isolation of infected person. The table revealed that $94.4 \%$ participants answered that isolation was necessary, $0.7 \%$ said that isolation was not necessary and $4.9 \%$ responded said they did not know about isolation of COVID-19 infected patient. (See Table 6)

Table 6. Distribution of knowledge about isolation of infected person $\mathrm{n}=305$

\begin{tabular}{|l|c|c|}
\hline \multicolumn{1}{|c|}{ Isolation is necessary for the infected person } & Frequency & Percent \\
\hline Yes & 288 & 94.4 \\
\hline No & 2 & 0.7 \\
\hline Don't know & 15 & 4.9 \\
\hline Total & 305 & 100.0 \\
\hline
\end{tabular}

Knowledge about quarantine. The study measured knowledge of the participants about quarantine. The table described that $68 \%$ participants agreed that quarantine was required for those who had exposed to COVID-19 infected person. 64.7\% said that in quarantine people stayed separated in institution or at home at least 14 days. $27.4 \%$ participants answered that quarantine helps to prevent spread of COVID-19 and 7.3\% answered that they did not know about quarantine (See Table 7).

Table 7. Distribution of knowledge about quarantine

$\mathrm{n}=305$

\begin{tabular}{|l|l|l|}
\hline \multicolumn{1}{|c|}{ Quarantine of COVID-19 } & Frequency & Percentage \\
\hline $\begin{array}{l}\text { Quarantine is required for those who have had exposed to } \\
\text { someone with COVID-19 }\end{array}$ & 206 & $68.0 \%$ \\
\hline $\begin{array}{l}\text { In quarantine people stay separated at home or institution } \\
\text { for at least 14 days. }\end{array}$ & 196 & $64.7 \%$ \\
\hline Quarantine helps to prevent spread of COVID-19 & 83 & $27.4 \%$ \\
\hline Don't Know & 22 & $7.3 \%$ \\
\hline Others & 4 & $1.3 \%$ \\
\hline
\end{tabular}


Sources of information. The participants were asked about the sources from where they were informed about COVID-19. The respondents had option to select multiple answers. Majority of them about $86.2 \%$ selected television as a source of information, the next option was social media which was $68.5 \%$, newspaper was $50.5 \%$, radio was $41.6 \%, 35.7 \%$ from working institutions and only $15.4 \%$ were answered that they had got information from health personnel (See table 8).

Table 8. Distribution of source Information

$\mathrm{n}=305$

\begin{tabular}{|l|c|c|}
\hline \multicolumn{1}{|c|}{ Sources of information of COVID-19 } & Frequency & Percentage \\
\hline social Media & 209 & $68.5 \%$ \\
\hline Newspaper & 154 & $50.5 \%$ \\
\hline Television & 263 & $86.2 \%$ \\
\hline Radio & 127 & $41.6 \%$ \\
\hline Health Personnel & 47 & $15.4 \%$ \\
\hline Working institutions & 109 & $35.7 \%$ \\
\hline Family members, relatives and friends & 78 & $25.6 \%$ \\
\hline Others & 10 & $3.3 \%$ \\
\hline
\end{tabular}

*(Participants selected multiple answers)

\subsection{Level of risk perception}

Most of the participants perceived that they had possibility of getting infection. 216 $(70.8 \%)$ answered likely, 44.4(14.4\%) said very likely, 23(7.5\%) participants answered don't know, $17(5.6 \%)$ said unlikely, and only 5(1.6\%) answered very unlikely. The majority of the respondents perceived that the chance of transmission of COVID-19 through colleagues was likely $(54.1 \%$ ), very likely $(39 \%)$, unlikely $3.3 \%$, only $03 \%$ very unlikely. Among the participants 3.3\% answered that they did not know. 52.5\% participants seemed that likely to spread of the infection to their family member, $37 \%$ very likely, $5.9 \%$ unlikely, $3 \%$ did not know about the possibility and only $1.6 \%$ thought very unlikely.

The results showed that $50.5 \%$ participants perceived that after getting infection severity of COVID-19 was very likely, $33.8 \%$ likely. Only $0.7 \%$ thought that severity of the disease was very unlikely. The perception about death from COVID-19 was $42.6 \%$ likely to death, $41 \%$ very likely, $1 \%$ thought very unlikely and 14.4 answered that they did not know. There were five questions about risk perception which answers were arranged in five-point Likert scale. The mean score of risk perception among the participants was 4.061 with standard deviation $( \pm 0.04828)$. The maximum score was 5.00 and the minimum score was 1.00 .

Risk perception was categorized by utilizing original Bloom's cut-off point. Participants who obtained $80-100 \%$ points (4-5 average score) classified as high-risk perception, who acquired 60-79\% points (3-3.9 score) categorized as moderate risk perception and those who got below $60 \%$ points $(<3$ score) was considered as low risk perception. 
According to the calculation the table displayed that among the respondents $80 \%$ had high risk perception, $8.5 \%$ had moderate risk perception and $11.5 \%$ had low risk perception. (See Figure 1)

Figure 1. Level of risk perception

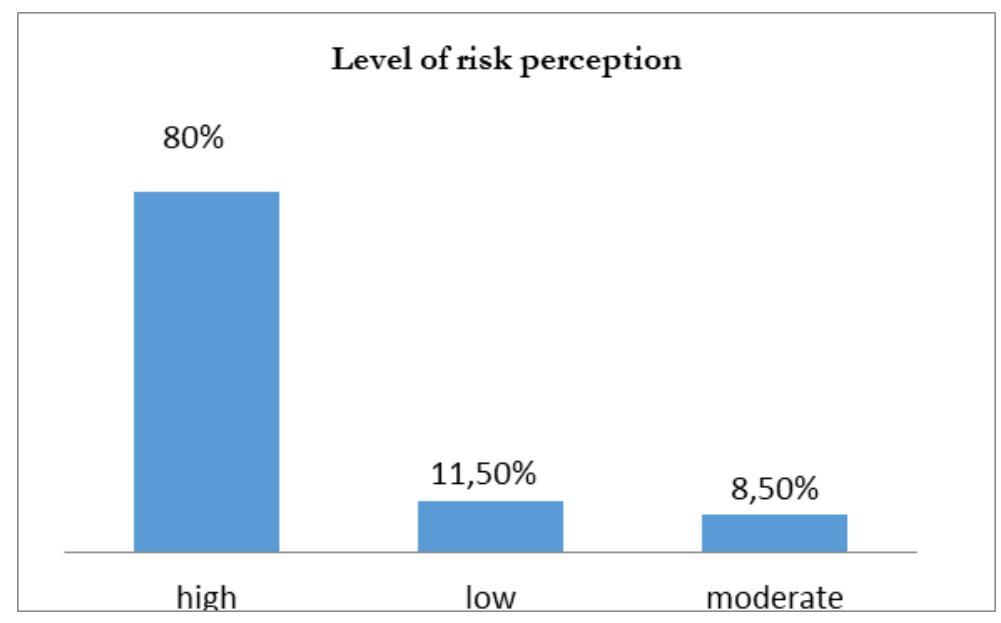

isk perception, $19.8 \%$ had moderate risk perception and $11.6 \%$ had low risk perception. Among the female $64.5 \%$ had high risk perception, $20.8 \%$ had moderate risk perception and $14.8 \%$ had low risk perception. The finding showed that male had higher risk perception than female participants (See Table 9)

Table 9. Distribution of level of risk perception between genders

$$
\mathrm{n}=305
$$

\begin{tabular}{|l|c|c|c|c|}
\hline \multirow{2}{*}{ Gender } & \multicolumn{3}{|c|}{ Risk perception level } & Total \\
\cline { 2 - 5 } & High & Moderate & Low & \\
\hline Male & $99(68.6 \%)$ & $11(19.8 \%)$ & $12(11.6 \%)$ & 122 \\
\hline Female & $145(64.5 \%)$ & $15(20.8 \%)$ & $23(14.8 \%)$ & 183 \\
\hline Total & 244 & 35 & 26 & 305 \\
\hline
\end{tabular}

\subsection{Level of practices towards COVID-19}

The participants were asked about their daily practices to fight against COVID-19. The answered were designed with five-point Likert scale. The average mean scores of preventive practices were $4.1779 \pm 0.58$. The results displayed that most of the 
participants (54.1\%) washed their hands with soap frequently, 29.2\% always, $15.7 \%$ sometimes and rest of the participants answered rarely $(0.7 \%)$ and never $(0.3 \%) .68 .2 \%$ participants put on face mask always during going to outside, $24.3 \%$ frequently, $5.6 \%$ sometimes. only $5(1.6 \%)$ answered that they used face mask rarely (See Table 10).

Table 10. Practices towards COVID-19

$\mathrm{n}=305$

\begin{tabular}{|l|c|c|c|c|c|c|}
\hline \multicolumn{1}{|c|}{$\begin{array}{c}\text { Practices towards } \\
\text { COVID-19 }\end{array}$} & $\begin{array}{c}\text { Never } \\
\mathbf{( \% )}\end{array}$ & $\begin{array}{c}\text { Rarely } \\
\mathbf{( \% )}\end{array}$ & $\begin{array}{c}\text { Sometimes } \\
\mathbf{( \% )}\end{array}$ & $\begin{array}{c}\text { Frequently } \\
\mathbf{( \% )}\end{array}$ & $\begin{array}{c}\text { Always } \\
\mathbf{( \% )}\end{array}$ & $\begin{array}{c}\text { Total } \\
\mathbf{( \% )}\end{array}$ \\
\hline $\begin{array}{l}\text { Hand washing with } \\
\text { soap }\end{array}$ & 0.3 & 0.7 & 15.7 & 54.1 & 29.2 & 100.0 \\
\hline Use of face mask & 0.0 & 1.6 & 5.6 & 24.3 & 68.5 & 100.0 \\
\hline $\begin{array}{l}\text { Maintain cough } \\
\text { etiquette }\end{array}$ & 0.0 & 0.7 & 12.1 & 30.5 & 56.7 & 100.0 \\
\hline $\begin{array}{l}\text { Maintain physical } \\
\text { distancing }\end{array}$ & 1.0 & 5.6 & 13.8 & 24.9 & 54.8 & 100.0 \\
\hline Avoid sick person & 5.2 & 4.9 & 3.6 & 24.9 & 61.3 & 100.0 \\
\hline $\begin{array}{l}\text { Avoid touching with } \\
\text { unclean hand }\end{array}$ & 27.9 & 4.6 & 10.5 & 29.8 & 27.2 & 100.0 \\
\hline $\begin{array}{l}\text { Avoid public } \\
\text { gathering }\end{array}$ & 2.0 & 3.9 & 9.2 & 31.1 & 53.8 & 100.0 \\
\hline use of hand sanitizer & 2.0 & 5.6 & 14.1 & 33.1 & 45.2 & 100.0 \\
\hline
\end{tabular}

Majority of the participants $(56.7 \%)$ always maintained cough etiquette, $30.5 \%$ frequently and the remaining of the participants answered sometimes $(12.1 \%)$, rarely (0.7 \%.). 54.8\% participants replied always maintained physical distancing during working hour, $24.9 \%$ frequently, $13.8 \%$ sometimes and the rest of them maintained rarely $(5.6 \%)$, never $(1 \%)$. Most of the participants $(61.3 \%)$ avoided meeting sick and infectious persons always. $24.9 \%$ participants answered that they avoided frequently, and remaining 3.6\% sometimes, $4.9 \%$ rarely and 5.2\% never avoided meeting sick persons. $29.8 \%$ participants answered that they frequently avoid touching face, nose, eyes by unclean hands, $27.2 \%$ always, $10.5 \%$ sometimes, $4.6 \%$ rarely and $27.9 \%$ never avoided to touch. Most of the respondents (53.8\%) avoided public gathering, $31.1 \%$ frequently, 9.2\% sometimes and $2 \%$ never kept away from public gathering. $45.2 \%$ participants answered that they always used hand sanitizer, $33.1 \%$ frequently used, $14.1 \%$ sometimes used, $5.6 \%$ rarely used and $2 \%$ never used hand sanitizer.

Level of Practices. The score of practices was simplified by using of Bloom's cut-off point. The participants who secured $80-100 \%$ points of score were judged as good practice, points within $60-79 \%$ were considered as fair practice and the participants whose score below $60 \%$ were categorized as poor practice. The table depicted that $76 \%$ participants had good practice, $19 \%$ had fair practice and $5 \%$ had poor practice. (See Figure 2). 
74 | Risk perception and the practices towards Covid-19

Figure 2. Level of practices

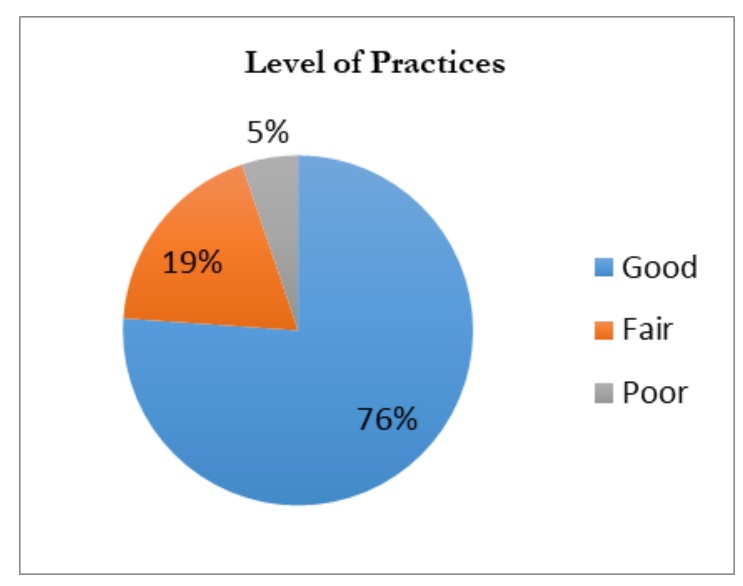

Gender and level of practices towards COVID-19. The results revealed that among the male respondents $77.87 \%$ had good practice, $17.21 \%$ had fair practice and $4.92 \%$ had poor practice. Among the female respondents $74.86 \%$ had good practice, $19.67 \%$ had fair practice and $5.46 \%$ had poor practice of preventive measures regarding COVID-19. (See Table 11). The finding showed that male had higher risk perception than female respondents.

Table 11. Distribution of level of practice between genders

$\mathrm{n}=305$

\begin{tabular}{|l|c|c|c|c|}
\hline \multirow{2}{*}{ Gender } & \multicolumn{3}{|c|}{ Practice level } & Total \\
\cline { 2 - 5 } & Good & Fair & Poor & \\
\hline Male & $95(77.87 \%)$ & $21(17.21 \%)$ & $6(4.92 \%)$ & 122 \\
\hline Female & $137(74.86 \%)$ & $36(19.67 \%)$ & $10(5.46 \%)$ & 183 \\
\hline Total & 232 & 57 & 16 & 305 \\
\hline
\end{tabular}

\subsection{Distribution of respondents that had fever}

In the study participants were asked about fever in last six months, among 305 participants $41.0 \%$ answered yes and $59.0 \%$ replied no. The respondents, who were suffering from fever in last six months, performed COVID-19 test 14.1\%. All the test results were negative (See Table 12 and 13). 
Table 12. Distribution of respondents had fever

$$
\mathrm{n}=305
$$

\begin{tabular}{|c|c|c|}
\hline Fever in last six months & Frequency & Percent (\%) \\
\hline Yes & 125 & 41.0 \\
\hline No & 180 & 59.0 \\
\hline $\mathrm{n}$ & 305 & 100.0 \\
\hline
\end{tabular}

Table 13. Distribution of respondents had COVID-19 test

$$
\mathrm{n}=125
$$

\begin{tabular}{|c|c|c|}
\hline COVID-19 test & Frequency & Percent (\%) \\
\hline Yes & 43 & 34.4 \\
\hline no & 82 & 65.6 \\
\hline Total & 125 & 100.00 \\
\hline
\end{tabular}

\subsection{Distribution of family members of respondents had fever}

The participants were requested to provide information about fever in last six months of their family members. The results demonstrate that $79(25.9 \%)$ participant's family member had symptoms like fever and $74.1 \%$ had no symptoms. Having COVID-19 related symptoms like fever among the family members of the respondents got tested COVID-19 24 (30.4\%). Among them $2(8.3 \%)$ of family members were found COVID-19 test positive (See Tables 14, 15 and 16).

Table 14. Distribution of family member had fever

$$
\mathrm{n}=305
$$

\begin{tabular}{|c|c|c|}
\hline Fever of family member & Frequency & Percent (\%) \\
\hline Yes & 79 & 25.9 \\
\hline No & 226 & 74.1 \\
\hline n & 305 & 100.0 \\
\hline
\end{tabular}

Table 15. Distribution of family member had COVID-19 test

\begin{tabular}{|c|c|c|}
\hline COVID-19 test & Frequency & Percent (\%) \\
\hline Yes & 24 & 30.4 \\
\hline no & 55 & 69.6 \\
\hline Total & 79 & 100 \\
\hline
\end{tabular}


76 | Risk perception and the practices towards Covid-19

Table 16. Distribution of COVID-19 test results of family members

\begin{tabular}{|c|c|c|}
\hline COVID-19 test results & Frequency & Percent (\%) \\
\hline Positive & 2 & 8.3 \\
\hline Negative & 22 & 91.7 \\
\hline Total & 24 & 100.00 \\
\hline
\end{tabular}

\subsection{Association of socio demographic characteristics with level of risk perception and level of practice}

Among the socio demographic characteristics age and housing status of the participants had significant relationship with level of risk perception. Participants of age 32- 39 years had high risk perception $(86.8 \%)$ which is statistically significant $(\mathrm{p}<0.029)$. participants were living in sublet had high risk perception $(89.3 \%)$ which is statistically significant $(\mathrm{p}<0.0001)$ (See Table 17 and 18).

Table 17. Age of the respondents and level of risk perception

\begin{tabular}{|c|c|c|c|c|c|c|c|}
\hline \multirow{2}{*}{$\begin{array}{l}\text { Age group } \\
\text { of } \\
\text { respondents }\end{array}$} & \multicolumn{4}{|c|}{ Level of risk perception } & $\chi^{2}$ test & $\mathrm{df}$ & b- \\
\hline & $\begin{array}{l}\text { High } \\
\mathrm{f}(\%)\end{array}$ & $\begin{array}{c}\text { Moderate } \\
\mathrm{f}(\%)\end{array}$ & $\begin{array}{l}\text { low } \\
\mathrm{f}(\%)\end{array}$ & Total & \multirow{6}{*}{17.083} & \multirow{6}{*}{8} & \multirow{6}{*}{0.029} \\
\hline $18-25$ years & $\begin{array}{c}88 \\
(75.9 \%)\end{array}$ & $\begin{array}{c}12 \\
(10.3 \%\end{array}$ & $\begin{array}{c}16 \\
(13.8 \%)\end{array}$ & 116 & & & \\
\hline $25-32$ years & $\begin{array}{c}94 \\
(82.5 \%)\end{array}$ & $\begin{array}{c}11 \\
(9.6 \%)\end{array}$ & $\begin{array}{c}9 \\
(7.9 \%)\end{array}$ & 114 & & & \\
\hline $32-39$ years & $\begin{array}{c}59 \\
(86.8 \%)\end{array}$ & $\begin{array}{c}2 \\
(2.9 \%)\end{array}$ & $\begin{array}{c}7 \\
(10.3 \%)\end{array}$ & 68 & & & \\
\hline $39-46$ years & $\begin{array}{c}3 \\
(50.0 \%)\end{array}$ & $\begin{array}{c}1 \\
(16.7 \%)\end{array}$ & $\begin{array}{c}2 \\
(33.3)\end{array}$ & 6 & & & \\
\hline $\begin{array}{l}46 \text { years } \\
\text { and above }\end{array}$ & $\begin{array}{c}0 \\
(0.0 \%)\end{array}$ & $\begin{array}{c}0 \\
(0.0 \%)\end{array}$ & $\begin{array}{c}1 \\
(100.0 \%)\end{array}$ & 1 & & & \\
\hline
\end{tabular}

Table 18. Housing status and level of risk perception

\begin{tabular}{|c|c|c|c|c|c|c|c|}
\hline \multirow{2}{*}{$\begin{array}{l}\text { Housing of } \\
\text { respondents }\end{array}$} & \multicolumn{3}{|c|}{ Level of risk perception } & \multirow[t]{2}{*}{ Total } & $\chi^{2}$ test & $\mathrm{df}$ & p-value \\
\hline & $\begin{array}{l}\text { High } \\
\mathrm{f}(\%)\end{array}$ & $\begin{array}{c}\text { Moderate } \\
\mathrm{f}(\%)\end{array}$ & $\begin{array}{l}\text { low } \\
\mathrm{f}(\%)\end{array}$ & & \multirow{4}{*}{22.350} & \multirow{4}{*}{4} & \multirow{4}{*}{0.0001} \\
\hline $\begin{array}{l}\text { Living with joint } \\
\text { family }\end{array}$ & $\begin{array}{c}44 \\
(74.6 \%) \\
\end{array}$ & $\begin{array}{c}11 \\
(18.6 \%)\end{array}$ & $\begin{array}{c}4 \\
(6.8 \%)\end{array}$ & 59 & & & \\
\hline Sublet & $\begin{array}{c}108 \\
(89.3 \%)\end{array}$ & $\begin{array}{c}6 \\
(5.0 \%)\end{array}$ & $\begin{array}{c}7 \\
(5.8 \%)\end{array}$ & 121 & & & \\
\hline $\begin{array}{l}\text { Living with } \\
\text { nuclear family }\end{array}$ & $\begin{array}{c}92 \\
(73.6 \%)\end{array}$ & $\begin{array}{c}9 \\
\left(7.2^{\circ} \%\right)\end{array}$ & $\begin{array}{c}24 \\
\left(19.2^{\circ} \%\right)\end{array}$ & 125 & & & \\
\hline
\end{tabular}


Socio demographic characteristics and level of practice. Respondents who were living in sublet had good level of practice $(90.1 \%)$ that is statistically significant $(\mathrm{p}<0.0001)$. Other socio demographic characteristic had no significant relationship with level of practice towards COVID19 (See Table 19).

Table 19. Housing status and level of practice

\begin{tabular}{|c|c|c|c|c|c|c|c|}
\hline \multirow[t]{2}{*}{$\begin{array}{l}\text { Housing of } \\
\text { respondents }\end{array}$} & \multicolumn{3}{|c|}{ Level of practice } & \multirow[t]{2}{*}{ Total } & $\chi^{2}$ test & $\mathrm{df}$ & p-value \\
\hline & $\begin{array}{c}44 \\
(74.6 \%)\end{array}$ & $\begin{array}{c}14 \\
(23.7 \%)\end{array}$ & $\begin{array}{c}1 \\
(1.7 \%)\end{array}$ & & \multirow{4}{*}{28.403} & \multirow{4}{*}{4} & \multirow{4}{*}{0.0001} \\
\hline $\begin{array}{l}\text { Living with } \\
\text { joint family }\end{array}$ & $\begin{array}{c}109 \\
(90.1 \%)\end{array}$ & $\begin{array}{c}10 \\
(8.3 \%)\end{array}$ & $\begin{array}{c}2 \\
(1.7 \%)\end{array}$ & 59 & & & \\
\hline Sublet & $\begin{array}{c}89 \\
\left(63.2^{\%} \%\right) \\
\end{array}$ & $\begin{array}{c}33 \\
(26.4 \%)\end{array}$ & $13(10.4 \%)$ & 121 & & & \\
\hline $\begin{array}{l}\text { Living with } \\
\text { nuclear } \\
\text { family }\end{array}$ & $\begin{array}{c}44 \\
(74.6 \%)\end{array}$ & $\begin{array}{c}14 \\
(23.7 \%)\end{array}$ & $\begin{array}{c}1 \\
(1.7 \%)\end{array}$ & 125 & & & \\
\hline
\end{tabular}

\subsection{Relationship between Risk perception and Practices of COVID-19}

Relationship between average risk perception and average practices towards COVID-19 was examined by using descriptive statistics tools. The result shows that the mean value of perception of COVID-19 by the respondents is 4.0610 with standard deviation of $( \pm$ 0.84313 ) and the mean value of the practices towards COVID-19 is 4.1975 with standard deviation of $( \pm 0.69027)$ where $\mathrm{N}$ was 305 . The result clearly indicates that the mean of average practices is higher than the mean of risk perception. The study used bivariate correlation to establish the relationship between risk perception and the practices. The result illustrates that the value of Pearson correlation coefficient $r=0.224$, $\mathrm{N}=305, \mathrm{p}$ value $<0.0001$. This finding represents that there is a weak positive correlation which is significant at the 0.01 level (See Table 20).

Table 20. Relationship between average risk perception and the practices towards COVID-19

\begin{tabular}{|c|c|c|}
\hline Characteristics & $\begin{array}{c}\text { Correlation coefficient } \\
\text { (r) }\end{array}$ & p-value \\
\hline $\begin{array}{l}\text { Average risk perception and } \\
\text { average practices of the } \\
\text { participants towards COVID-19 }\end{array}$ & 0.224 & 0.0001 \\
\hline
\end{tabular}


The results demonstrated that $80 \%$ of the participants had high risk perception. Chi square test showed that among the participants of having high risk perception $80.3 \%$ had good practice, $16.0 \%$ had fair practice and $3.7 \%$ had poor practice of preventive behaviors of COVID-19. The table also displays that $11.5 \%$ of participants had low risk perception, among them $54.3 \%$ had good practice, $34.3 \%$ had fair practice and $11.4 \%$ had poor practice. $8.5 \%$ of the participants enclosed moderate risk perception. Participants with moderate risk perception $65.4 \%$ had good practice, $23.1 \%$ had fair practice and $11.5 \%$ had poor practice. The results obviously depict that the participants having higher risk perception had higher tendency of good practice of protective behaviors against COVID-19 (See Table 21).

Table 21. Association between level of risk perception and level of the practices towards COVID-19

$\mathrm{n}=305$

\begin{tabular}{|c|c|c|c|c|c|c|c|}
\hline \multirow{2}{*}{$\begin{array}{c}\text { Level of } \\
\text { risk } \\
\text { perception }\end{array}$} & \multicolumn{3}{|c|}{ Level of practice } & Total & $\begin{array}{c}\chi^{2} \text { test } \\
\text { value }\end{array}$ & df & p-value \\
\cline { 2 - 4 } \cline { 3 - 4 } & $\begin{array}{c}\text { Good } \\
\mathrm{f}(\%)\end{array}$ & $\begin{array}{c}\text { Fair } \\
\mathrm{f}(\%)\end{array}$ & $\begin{array}{c}\text { Poor } \\
\mathrm{f}(\%)\end{array}$ & & & & \\
\hline High & $\begin{array}{c}196 \\
(80.3 \%)\end{array}$ & $39(16.0 \%)$ & $\begin{array}{c}9 \\
(3.7 \%)\end{array}$ & 244 & \multirow{2}{*}{14.576} & \multirow{2}{*}{4} & \multirow{2}{*}{0.006} \\
\hline Moderate & $\begin{array}{c}17 \\
(65.4 \%)\end{array}$ & $\begin{array}{c}6 \\
(23.1 \%)\end{array}$ & $3(11.5 \%)$ & 26 & & \\
\hline low & $\begin{array}{c}19 \\
(54.3 \%)\end{array}$ & $\begin{array}{c}12 \\
(34.3 \%)\end{array}$ & $4(11.4 \%)$ & 35 & & & \\
\hline
\end{tabular}

The results displayed that the calculated Pearson Chi-Square value at df 4, p 0.05 is 14.576 which is greater than tabulated Chi-Square value $(\chi 24,305)=14.576, p=0.006$. The result showed $\mathrm{p}$ value is 0.006 which is significant

\subsection{Observation on working environment}

The management personnel were asked about the protective measures that were taken in their institutes. They were inquired that the institute maintained physical distancing during working hours, supplied hand sanitizer or soap, face mask and provided adequate water supply. The answer of these questions was dichotomous. The administrative personnel of all factories provided the positive response. It was observed that the measures were taken by the management of garment factories to prevent COVID-19.

\section{Major findings and discussions}

On the basis of objective of assessing the level of risk perception and the practices towards COVID-19 among the garment workers and to estimate the relationship between risk perception and the practices, this section made an effort to examine the results aligned with the research objectives and the variables of the study. Moreover, it has been attempted to discuss the major findings of this study with existing literatures 
and related previous studies of other scholars on knowledge, attitude, risk perception and the practices about COVID-19.

\subsection{Socio-demographic characteristics}

Female and male respondents of this study were $60 \%$ and $40 \%$ respectively. Mean age of the participants was 28.40 years with $\mathrm{SD} \pm 5.696$ and median age was 27.39 years. Most of the participants were Muslims (84.3\%) and $79 \%$ participants were married. Among 305 respondents $32.8 \%$ lived in a room with three members. Majority of respondents $(47.9 \%)$ and their spouse $(41.3 \%)$ completed secondary level of education. It was found that $45.6 \%$ of the participant's spouses were working in the garment industries and only $1.6 \%$ was unemployed. Similarly a study was conducted among garment workers revealed that most of the participant's age was20-22 years, male $(51.8 \%)$ were slightly higher than female $(48.2 \%)$ participants, $58.2 \%$ had completed secondary level of education which was higher than the study $(47.9 \%), 60 \%$ were living with nuclear family which was alike the study , 57.3\% lived in sublet in colony which was lower proportion the study (39.7\%) (Abdullah-Al-Nahid, 2019).

\subsection{Knowledge regarding Covid-19}

The study revealed that the largest part of the participants answered that symptoms of Covid-19 were fever $(97.7 \%)$, dry cough $(77 \%)$, and sore throat $(72.8 \%)$, difficulty in breathing (63\%), headache (59.3\%), and diarrhea (24.6\%).Mya et al., 2020, in their study found that $57.4 \%$ replied fever, $59.4 \%$ cough, and $36.1 \%$ difficulty in breathing, $14.1 \%$ fatigue and 1.7\% mentioned diarrhea as symptoms of Covid-19 (Mya et al., 2020). Similarly a study revealed more than $91 \%$ respondents mentioned fever was a symptom of COVID19 next $78.4 \%$ difficulty in breathing, $55.1 \%$ headache, $49.8 \%$ sore throat and $16.4 \%$ diarrhea (Wadood, Mamun and Rafi, 2020).Similarly, Zegarra-Valdivia, Ames-Guerrero, 2020, in their study in Peru found alike the results of this study. A study conducted among health care workers (HCWs) in Vietnam, 99.1\% participants answered that Covid-19 is a viral disease, $67 \%$ knew that the virus is spread by close contact with the infected person and more than $98 \%$ opined that it could be prevented by hand washing with soap and using face mask(Huynh et al., 2020), this percentage were higher than this study.

Source of information. Among 305 respondents two hundred sixty-three got information from television, 203 participants searched out information from social media, 154 from newspaper, 109 from radio, 109 from working places, 78 from family members, relatives, and friends and only 47 from health personnel. Another study showed that most of the respondents grasped information from mass media $(81.5 \%)$ and other sources which is higher than this study (Olapegba et al., 2020).

\subsection{Risk perception about COVID-19}

This study estimated that the mean and median of average risk perception is $4.0610 \pm$ 0.84313 and 4.4 respectively. The results show that $80 \%$ assumed high risk, $8.5 \%$ 
moderate and $11.5 \%$ low risk perception level. A similar type of study in Kurdistan Region, Iraq found that $6.9 \%$ participants had perceived risk of being infected by corona virus highly likely, $4 \%$ respondent perceived risk of severity of illness and $5.7 \%$ participants perceived risk about death by COVID-19 was highly likely (Shabu, 2020).In this study the participants answered very likely about getting infection (41.7\%), severity $(50.5 \%)$ and possibility of death by COVID-19 (41\%). In comparison of the risk perception level was higher among the participants of this study than the study in Iraq. A study by Hussain et al., 2020, estimated risk perception was slightly higher in male $(68.6 \%)$ than the female $(64.5 \%)$. A study in South Korea showed that the risk perception was equal between male and female respondents (Husnayain et al., 2020).

\subsection{Practices towards Covid-19}

The findings showed that the mean and median of average practice was $4.1779 \pm 0.58798$ and 4.3750 respectively. Level of practice revealed that $76 \%$ participants executed good practice, $19 \%$ carried out fair practice and $5 \%$ had poor practice. The extent of good practice $(76 \%)$ was higher in compared to other study conducted in Gamo zone, southern Ethiopia (35.3\%) (Abera Mersha1 et al., 2020). Other studies conducted in Bangladesh showed that the level of good practice among the respondents was $71 \%$ (Wadood et al., 2020) and in Iran 16.7\% participants showed excellent practice (Erfani, Shahriarirad and Ranjbar, 2020) which were lower than this study. On the other hand a study demonstrated that $88.7 \%$ respondents had good practice(Muhammad saqlain et al., 2020). SimaRugarabamu, Marium Ibrahim, 2020, in their study showed that the participants avoided visiting crowded place $(77 \%)$ and used face mask during going outside $(80 \%)$ that rate were higher than this study. A similar study in Nepal showed that among the participants $93.4 \%$ practiced social distancing and $94.7 \%$ practiced hand washing (Hussain et al., 2020), which was greater than this study because more than $50 \%$ participants were health workers.

\subsection{Working environment}

In this study working environment was defined as congenial workplace that can limit the spread of COVID-19. Sen et al., stated in their study that working environment of apparel industries was not satisfactory usually unsafe and unhygienic and the garment employees were often affected by communicable diseases. Many studies mentioned about the inadequate working environment of readymade garment factories (Sen, Antara, et al., 2020). The study showed that among 305 participants nobody had Covid-19 test positive. This finding was similar with the study conducted in Iraq (Shabu, 2020).

\section{Conclusion and Recommendations}

\subsection{Conclusions}

This cross-sectional study gave emphasis on knowledge, risk perception and practices of precautionary measures towards COVID-19 among the garment workers. Most of 
the respondents were well known about the type, contagiousness, symptoms, mode of transmission, and ways of prevention of COVID-19. The majority of the respondents were highly perceived of getting infection, the severity of the disease and possibility of death from COVID-19. A good number of the respondents had high level of risk perception. The majority of respondents followed the World Health Organization guidelines of protective measures such as washing hands with soap, using face mask, maintaining respiratory etiquette, maintaining physical distance, avoid touching with unclean hands and public gathering. More than three fourth of respondents had good level of practice towards COVID-19. This study revealed that there was a positive significant relationship between risk perception and the practices regarding COVID-19. This study was confined only among the few garment workers; risk perception and practices can be an area of further research for other industrial workers and public. The study has uncovered the importance of the theories developed by various scholars 'such as protection behavior theory, health belief model, value expectancy model, theory of reasoned action, Transtheoretical model. Hence the results of the study have contributed to the body of knowledge and theories on knowledge, risk perception and practices towards COVID-19.

\subsection{Recommendations}

The major findings for this study exposed that risk perception and the practices are positively correlated. It is attempted to give the following recommendations for this study: i) Work place manager should monitor the workers to follow the preventive measures against COVID-19 as such wearing face mask; ii) the management of the work places should invigilate the workers as regards hand washing to improve the level of practices; iii) through awareness it can be improve cough etiquette, keep away touching face, nose and eyes by unclean hands, avoid public gathering and use hand sanitizer; iv) health education program should be enhanced to disseminate information about COVID-19 that will develop knowledge, attitude, perception and practices towards COVID-19 and v) The results of the study indicate that there is a significant association between risk perception and the practices towards COVID-19. Hence, it is recommended that the risk perception should be increased by proper knowledge about the severity of COVID-19.

\section{Declaration}

This thesis entitled "Risk Perception and the Practices towards COVID-19 among the Garment Workers" is submitted to the faculty of Preventive and Social Medicine of Bangabandhu Sheikh Mujib Medical University (BSMMU), Dhaka and I do hereby, declare that the research work reported in this thesis has been performed by me and this work has not been submitted elsewhere for the award of any other degree.

\section{Acknowledgement}

At the outset, I am thankful to the Almighty Allah, the most Gracious and most Merciful for giving me enough strength and patience to perform and complete this 
research work. I would like to express my heartiest gratitude to my respected supervisor Dr. Shafia Shaheen, Assistant Professor, Department of Epidemiology, NIPSOM, and other mentors and the participants of the studies. I owe a debt to my parents and family members for their continuous support.

\section{References}

Abdelrahman, M. (2020) Personality Traits, Risk Perception, and Protective Behaviors of Arab Residents of Qatar During the COVID-19 Pandemic, International Journal of Mental Health and Addiction, (Merson 2006). doi: 10.1007/s11469-020-00352-7.

Abdulah, D. M. et al. (2020) Response of the Public to Preventive Measures of COVID-19 in Iraqi Kurdistan, Disaster Medicine and Public Health Preparedness, p. 1-9. doi: 10.1017/dmp.2020.233.

Abdullah-Al-Nahid, S. (2019) Assessment, Monitoring, and Awareness of Garment Workers Regarding the Prevalence of Tuberculosis in Savar, Dhaka, European Journal of Medical and Health Sciences, 1(5), p. 30-40. doi: 10.34104/ejmhs.03040.

Abera M et al.. (2020) Health professionals practice and associated factors towards precautionary measures for COVID-19 pandemic in public health facilities of Gamo zone, southern Ethiopia: a cross- sectional study. doi: https://doi.org/10.1101/ 2020.09.05.20188805.

Al-Hazmi, A. et al. (2018) Knowledge, attitude and practice of secondary schools and university students toward Middle East Respiratory Syndrome epidemic in Saudi Arabia: A cross-sectional study, Saudi Journal of Biological Sciences. King Saud University, 25(3), p. 572-577. doi: 10.1016/j.sjbs.2016.01.032.

Aruhomukama, D. et al. (2020) Face-masking, an acceptable protective measure against COVID-19: Findings of Ugandan high-risk groups, medRxiv, p. 2020.08.29.20184325. Available at: https://doi.org/10.1101/2020.08.29.20184325.

Azlan, A. A. (2020) Public knowledge, attitudes and practices towards COVID-19: A crosssectional study in Malaysia, p. 1-15.

Bedford, J. et al. (2020) COVID-19: towards controlling of a pandemic, The Lancet, 395(10229), p. 1015-1018. doi: 10.1016/S0140-6736(20)30673-5.

Bruine de Bruin, W. and Bennett, D. (2020) Relationships Between Initial COVID-19 Risk Perceptions and Protective Health Behaviors: A National Survey, American Journal of Preventive Medicine, 59(2), p. 157-167. doi: 10.1016/j.amepre. 2020.05.001.

Chan, E. Y. Y. et al. (2020) Socio-demographic predictors of health risk perception, attitude and behavior practices associated with health-emergency disaster risk management for biological hazards: The case of COVID-19 pandemic in Hong Kong, SAR China, International Journal of Environmental Research and Public Health, 17(11), p. 1-18. doi: 10.3390/ijerph17113869.

Chowdhury, N. J \& Ullah, M. H. (2010) Socio-economic conditions of female Garment Workers in Chittagong Metropolitan Area: An Empirical Study, Journal of Business and technology, 5, p. 53-70.

Clubb, A. C. and Hinkle, J. C. (2015) Protection motivation theory as a theoretical framework for understanding the use of protective measures, Criminal Justice 
Studies, 28(3), p. 336-355. doi: 10.1080/1478601X.2015.1050590.

Cori, L. et al. (2020) Risk Perception and COVID-19, International Journal of Environmental Research and Public Health, 17(9). doi: 10.3390/ijerph17093114.

DeJoy, D. M. (1996) Theoretical models of health behavior and workplace selfprotective behavior, Journal of Safety Research, 27(2), p. 61-72. doi: 10.1016/00224375(96)00007-2.

DGHS (2020) COVID-19 DGHS. Available at: www.dghs.gov.bd.

Dryhurst, S. et al. (2020) Risk perceptions of COVID-19 around the world, Journal of Risk Research. Routledge, p. 1-13. doi: 10.1080/13669877.2020.1758193.

Erfani, A. et al. (2020) Knowledge, Attitude and Practice toward the Novel Coronavirus (COVID-19) Outbreak: A Population-Based Survey in Iran, Bulletin of the World Health Organization, 30 March 2(March). Available at: http://dx.doi.org/10.2471/BLT.20.256651.

Erfani, A., Shahriarirad, R. and Ranjbar, K. (2020) Knowledge, Attitude and Practice toward the Novel Coronavirus ( COVID-19) Outbreak $\square:$ A Population-Based Survey in Iran, (March).

Ferdous, M. Z. et al. (2020) Knowledge, attitude, and practice regarding COVID-19 outbreak in Bangladesh: An onlinebased cross-sectional study, PLoS ONE, 15(10 October), p. 1-17. doi: 10.1371/journal.pone.0239254.

Harapan, H. et al. (2020) Journal of Infection and Public Health Coronavirus disease 2019 ( COVID-19 ): A literature review, Journal of Infection and Public Health. King Saud Bin Abdulaziz University for Health Sciences, 13(5), p. 667-673. doi: 10.1016/j.jiph.2020.03.019.

Hossain, M. B. (2020) Global Outbreaks of SARS-nCoV-2 (COVID-19 Pandemic) and Spread out in Bangladesh, Bangladesh Journal of Infectious Diseases, 7(1), p. 38-41. doi: $10.3329 /$ bjid.v7i1.48676.

Husnayain, A. et al. (2020) Assessing the community risk perception toward COVID19 outbreak in South Korea: evidence from Google and NAVER relative search volume, medRxiv, p. 2020.04.23.20077552. doi: 10.1101/2020.04.23.20077552.

Hussain, A. et al. (2020) Knowledge, attitudes, and practices towards COVID-19 among Nepalese Residents: A quick online cross-sectional survey, Asian Journal of Medical Sciences, 11(3), p. 6-11. doi: 10.3126/ajms.v11i3.28485.

Huynh, G. et al. (2020) Knowledge and attitude toward COVID-19 among healthcare workers at District 2 Hospital, Ho Chi Minh City, Asian Pacific Journal of Tropical Medicine, 13(6), p. 260-265. doi: 10.4103/1995-7645.280396.

IEDCR (2020) Bangladesh Corona virus (Covid-19) update. Available at: www.iedcr.gov.bd.

Kebede, Y. et al. (2020) Knowledge, perceptions and preventive practices towards COVID-19 early in the outbreak among Jimma university medical center visitors, Southwest Ethiopia, PLoS ONE, 15(5), pp. 1-15. doi: 10.1371 /journal.pone.0233744.

Kwok, K. O. et al. (2020) Community responses during the early phase of the COVID19 epidemic in Hong Kong: risk perception, information exposure and preventive measures, medRxiv. doi: 10.1101/2020.02.26.20028217.

Luu, T. and Huynh, D. (no date) Volume 40 , Issue 1 The COVID-19 risk perception: A survey on socioeconomics and media attention, 40(1), pp. 758-764.

Mainous, A. G. (2020) A Towering Babel of Risk Information in the COVID-19 
84 | Risk perception and the practices towards Covid-19

Pandemic: Trust and Credibility in Risk Perception and Positive Public Health Behaviors, Family medicine, 52(5), p. 317-319. doi: 10.22454/ FamMed.2020.530121.

Md.Lokman Ali, D. N. I. (2017) Working Environment of Female Readymade Garment Workers in Bangladesh, (Center for Higher Studies and Research Bangladesh University of Professionals Mirpur), p. 1-12.

Muhammad S. et al. (2020) Knowledge, attitude, practice and perceived barriers among healthcare professionals regarding COVID-19: A Cross-sectional survey from Pakistan Muhmmad, American Journal of Sociology. doi: https://doi.org/ 10.1101/2020.04.13.20063198.

Mya, K. S. et al. (2020) Awareness, perceived risk and protective behaviours of Myanmar adults on COVID-19, International Journal Of Community Medicine And Public Health, 7(5), p. 1627. doi: 10.18203/2394-6040.ijcmph20201530.

Olapegba, P. O. et al. (2020) Survey data of COVID-19-related Knowledge, Risk Perceptions and Precautionary Behavior among Nigerians, Data in Brief. Elsevier Inc., 30, p. 105685. doi: 10.1016/j.dib.2020.105685.

Olum, R. and Bongomin, F. (2020) Coronavirus Disease-2019 $\square$ : Knowledge, Attitude, and Practices of Health Care Workers at Makerere University Teaching Hospitals, 8(April), pp. 1-9. doi: 10.3389/fpubh.2020.00181.

van der Pligt, J. (1996) Risk Perception and Self-Protective Behavior, European Psychologist, 1(1), p. 34-43. doi: 10.1027/1016-9040.1.1.34.

Prentice-Dunn, S., McMath, B. F. and Cramer, R. J. (2009) Protection motivation theory and stages of change in sun protective behavior, Journal of Health Psychology, 14(2), p. 297-305. doi: $10.1177 / 1359105308100214$.

Rad, R. E. (no date) Predicting COVID-19 Preventive Behaviors based on Protection Motivation Theory in Hormozgan, Iran Background $\square$ ':, p. 1-11.

Rashid*, M. M. U. and Rashid**, M. A. (2AD) 'Health and Safety Environment of readymade Garment Industry in Bangladesh: a case study of Zaheen Knitwears limited'.

Ronald, O. (2020) Social Media Platforms for Health Communication and Research in the Face of COVID-19 Pandemic: A Cross Sectional Survey in Uganda.

Sen, Shuvro, Ahmed, F., et al. (2020) Potential Public Health Threats to Ready Made Garments (RMG) Workers During COVID -19 in Bangladesh: A Call for Actions, SSRN Electronic Journal, (January). doi: 10.2139/ssrn.3665404.

Sen, Shuvro, Antara, N., et al. (2020) The apparel workers are in the highest vulnerability due to COVID-19 $\square$ : a study on the Bangladesh Apparel Industry, Asia Pacific Journal of Multidisciplinary Research, 8(3), pp. 1-7. Available at: https://www.apjmr.com/wp-content/uploads/2020/08/APJMR2020.8.3.02.01.pdf.

Serwaa, D. et al. (2020) Knowledge, risk perception and preparedness towards coronavirus disease-2019 (Covid-19) outbreak among ghanaians: A quick online cross-sectional survey, Pan African Medical Journal, 35(2), p. 1-7. doi: 10.11604/pamj.2020.35.2.22630.

Shabu, S. (no date) Risk perception and behavioral response to COVID-19 in Iraqi Kurdistan Region, p. 1-23. doi: 10.21203/rs.3.rs-22025/v1.

SimaRugarabamu, Marium Ibrahim, A. B. (2020) Knowledge, attitudes, and practices towards 
COVID-19 among Tanzanian Residents: A quick online cross-sectional survey'. doi: 10.3126/ajms.v11i3.28485.

Taghrir, M. H., Borazjani, R. and Shiraly, R. (2020) 'COVID-19 and Iranian Medical Students; A Survey on Their Related-Knowledge, Preventive Behaviors and Risk Perception', Archives of Iranian medicine, 23(4), pp. 249-254. doi: 10.34172/aim.2020.06.

Wadood, A., Mamun, A. and Rafi, A. (2020) Knowledge, attitude, practice and perception regarding C 1 OVID-19 among students in 2 Bangladesh: Survey in Rajshabi University. Available at: Pengetahuan Dan Sikap Mahasiswa Kesehatan Tentang Pencegahan Covid-19 Di Indonesia.

Wadood, M. et al. (2020) Practice and perception of Bangladeshi adults toward COVID-19: a cross-sectional study, p. 1-15. doi: 10.21203/rs.3.rs-29364/v1.

World Health Organization (no date) WHO Director-General's opening remarks at the mission briefing on COVID-19. 2020. Available at: WHO website.

Xiao, Y. and Torok, M. E. (2020) Taking the right measures to control COVID-19, The Lancet Infectious Diseases. Elsevier Ltd, 20(5), pp. 523-524. doi: 10.1016/S1473-3099(20)30152-3.

Zegarra-Valdivia, J. A. 1; Chino-Vilca, B. N. 1; \& Ames-Guerrero, R. 2 (no date) 'KAP in Regard to COVID-19 Pandemic in Peruvian Population'.

Zhong, B. L. et al. (2020) Knowledge, attitudes, and practices towards COVID-19 among Chinese residents during the rapid rise period of the COVID-19 outbreak: a quick online cross-sectional survey, International journal of biological sciences, 16(10), pp. 1745-1752. doi: 10.7150/ijbs.45221. 